\title{
Classroom Management in Basic Yellow Book Learning at The Pesantren
}

\section{Manajemen Kelas pada Pembelajaran Kitab Kuning Tingkat Dasar di Pesantren}

\author{
Hartono Hartono* \\ Institut Agama Islam Negeri (IAIN), Jember, Indonesia
}

Pesantren are traditional Islamic educational institutions which are never used up to be discussed and studied. One of the exciting things to study is how pesantren design basic "classes" so that they can make effective and efficient learning while staying oriented towards learning goals. And how do pesantren make "class" a secure emotional connection between teacher (kyai), student (santri), and teaching material (kitab kuning) in the class so that class harmonization appears within the typical scope of pesantrenstyle learning. Kitab Kuning learning in pesantren has a unique "model" in carrying out its education; this particularity is then interesting to be used as study material as another alternative in organizing education. Kitab Kuning learning in pesantren adheres to management that is different from class management in general, both in terms of curriculum structure, class construction, and interaction of existing learning components. In general, Kitab Kuning learning in pesantren is divided into 3 (three) levels, namely the primary level (Ula), the intermediate level (Wusta), and the upper level (Ulya). However, this research

OPEN ACCESS ISSN 2579-5813 (online)

Edited by:

Nurdyansyah

Reviewed by:

Ruli Astuti

*Correspondence:

Hartono Hartono

hartono2986@gmail.com

Received: 3 Januari 2020 Accepted: 10 Februari 2020

Published: 30 April 2020

Citation:

Hartono H (2020) Classroom Management in Basic Yellow Book

Learning at The Pesantren. Madrosatuna: Journal of Islamic

Elementary School. 4:1. doi: 10.21070/madrosatuna.v4i1.37 focuses more on the basic level (Ula), because this level is a determinant of success at the next grade level. Santri at the elementary level are not directly taught the Kitab Kuning, but were introduced first how to read and write the 'Pegon' Script. So, students who just entered were conditioned in such a way as to be more familiar with the 'Pegon' Script. Therefore, it will be discussed about the patterns and models of class management in the learning of the Kitab Kuning at As-Sunniyah Kencong Pesantren and Baitul Arqom Balung Pesantren in Jember Regency using behavior modification, socio-emotional, and group process approach, which is seen in the classroom conduciveness based on class conduciveness, the element of spirituality, namely the synergistic and harmonious interaction between the kiai, the teacher, and the santri in achieving the learning objectives.

Keywords: Class Management, Learning of Kitab Kuning, Elementary School, Pesantren

Pesantren merupakan lembaga pendidikan Islam tradisional yang tidak pernah habis untuk dibahas dan dipelajari. Salah satu yang menarik untuk dikaji adalah bagaimana pesantren dalam mendesain "kelas" tingkat dasar sehingga mampu menjadikan pembelajaran yang efektif dan efisien dengan tetap berorientasi pada tujuan pembelajaran. Serta bagaimana pesantren menjadikan "kelas" sebagai hubungan emosional yang kuat antara guru (kyai), murid (santri) dan bahan ajar (kitab kuning) di dalam kelas sehingga 
muncul harmonisasi kelas dalam lingkup pembelajaran yang khas ala pesantren. Pembelajaran kitab kuning di pesantren mempunyai "model" unik dalam melaksanakan pembelajarannya, ke-khas-an inilah yang kemudian menarik untuk dijadikan bahan kajian sebagai alternatif lain dalam penyelenggaraan pembelajaran. Pembelajaran kitab kuning di pesantren menganut manajemen berbeda dengan manajemen kelas pada umumnya, baik dalam hal struktur kurikulum, konstruksi kelas serta interaksi komponen pembelajaran yang ada. Secara umum, pembelajaran kitab kuning di pesantren dibagi menjadi 3 (tiga) tingkat, yakni tingkat dasar (Ula), tingkat menengah (Wusta), dan tingkat atas (Ulya). Namun, penelitian ini lebih memfokuskan pada tingkat dasar (Ula), karena tingkat ini menjadi penentu keberhasilan pada tingkat kelas berikutnya. Santri di tingkat dasar tidak langsung diajarkan kitab kuning secara langsung, tetapi diperkenalkan terlebih dahulu cara baca tulis Aksara Pegon. Jadi, para santri yang baru masuk dikondisikan sedemikian rupa agar lebih familier dengan Aksara Pegon. Oleh karena itu, akan dibahas tentang pola dan model manajemen kelas pada pembelajaran Kitab Kuning di Pesantren As-Sunniyah Kencong dan Pesantren Baitul Arqom Balung Kabupaten Jember dengan menggunakan pendekatan behavior modification, sosio-emotional, dan group process, yang tampak dalam kondusifitas kelas yang dilandasi unsur spiritualitas, yakni interaksi antara kiai, guru, dan santri yang sinergis dan harmonis dalam mencapai tujuan pembelajaran.

Kata Kunci: Manajemen Kelas, Pembelajaran Kitab Kuning, Pesantren Tingkat Dasar 


\section{PENDAHULUAN}

Banyak penelitian yang telah dilakukan dalam rangka mengungkap daftar panjang keluhan tentang pengelolaan pendidikan di pesantren yang berhubungan dengan kesiapan pesantren dalam mewujudkan proses pembelajaran yang berkualitas dan berdaya saing tinggi terutama dengan lembaga-lembaga pendidikan umum di luar pesantren. Asumsi bahwa pendidikan di pesantren sebagai strata pendidikan nomor dua juga belum sepenuhnya hilang dari masyarakat. Sama halnya dengan anggapan bahwa pesantren hanya tempat "rehabilitasi" bagi anak-anak nakal dan berkebutuhan khusus juga menjadi pendapat umum yang berkembang dalam masyarakat. Namun demikian, dalam persepsi yang lebih luas, di tengah-tengah tingginya tuntutan moral dan gejolak sosial tentang kualitas dan dekadensi moral dalam bermasyarakat, pesantren kemudian dihadirkan dalam memberikan harapan dan solusi riil sebagai salah satu alternatif yang dianggap mampu memberikan respon positif dalam membendung masalah-masalah moral tersebut. Tidak sedikit yang berusaha mengungkap kembali peran pesantren dalam menyiapkan lulusan-lulusan yang punya integritas tinggi dalam interaksi sosial masyarakat yang ada hampir di semua bidang, dimana lulusan pesantren mampu memberikan warna tersendiri dalam interaksi sosial dengan bekal pengetahuan yang didapat dari pesantren.

Pesantren sebagai salah satu penyelenggara pendidikan keislaman ditengarai sebagai cikal bakal pesatnya perkembangan pendidikan Islam saat ini. Keunikan pesantren sejauh ini masih banyak menjadi bahan kajian oleh para peneliti sebagai sebuah sumber yang menyimpan banyak hal terutama dalam kahzanah keilmuan dan pendidikan Islam. Kehadiran pesantren dikatakan unik karena dua alasan yakni: Pertama, pesantren hadir untuk merespon terhadap situasi dan kondisi suatu masyarakat yang dihadapkan pada runtuhnya sendi-sendi moral atau bisa juga disebut mengalami perubahan sosial. Kedua, didirikannya pesantren adalah untuk menyebar luaskan ajaran universalitas Islam ke seluruh pelosok Nusantara Soebahar (2013) . Pesantren adalah sebuah komunitas, di mana para ulama (kyai), guru (ustadz), siswa (santri), dan penguruspesantren tinggal bersamadi satu ma'had,berdasarkan nilai-nilai agama Islam lengkap dengan norma dan kebiasaan mereka,yang secara eksklusif berbeda dari populasi umum di sekitar mereka Sista et al. (2019) . Dalam perjalanannya, eksistensi pesantrentidak dapat diragukan lagi terutama dalam kapasitasnya sebagai pondasi pengembangan dan pelestarian nilainilai islam di masyarakat. Keberadaan pesantren yang nasih eksis dan mampu menyesuaikan dengan perkembangan zaman merupakan bukti bahwa pesantren dapat mengambil peran dalam setiap kebutuhan masyarakat terutama tentang pendidikan, moral dan nilai-nilai islam.

Pembelajaran Kitab Kuning di Pesantren pada dasarnya dibagi menjadi 3 (tiga) tingkatan, yaitu: tingkat dasar (Ula/Awaliyah) setingkat SD/MI yang ditempuh selama 4 tahun; tingkat menengah (Wustho) setingkat SMP/MTs yang ditempuh selama 3 tahun, dan tingkat atas ('Ulya) setingkat SMA/MA/SMK ditempuh selama 3 tahun. Namun, dalam penelitian ini penulis lebih memfokuskan pada tingkat dasar (Ula) karena tingkat dasar ini menjadi penentu keberhasilan pada tingkat kelas berikutnya, sehingga membutuhkan desain model manajemen kelas yang tepat. Materi yang diberikan pada tingkat dasar yaitu: al-Qur'an, Hadits, Nahwu, Sharaf, Fiqih, Ushul Fiqih, Tauhid, Akhlaq, dan bimbingan baca kitab kuning. Kitab-kitab yang digunakan pada tingkat dasar (Ula), untuk kelas I diantaranya: Sifa'ul Jinan, Aqidah Al-Awam, Awamil Jurjani, Akhlaq Lilbanin, Imla', dan Khot, serta Mabadi al-Fiqhiyah I. Kelas II diantaranya: Jurumiyah, Aqidah al-Islamiyah, Akhlaqul Lilbanin II, Qowa'idul I'lal, Mabadi alFiqhiyah II \& III, al-Amtsilah al-Tasrifyah. Sedangkan kelas III diantaranya: Jawahir al-Kalamiyah, Taisirul Kholaq, al-Amriti, al-Kaelani dan fiqh al-Wadih, dan diperkuat pula bimbingan baca Kitab Kuning.

Pembelajaran Kitab Kuning atau Kitab Gundul yang berlangsung di pesantren, khususnya pada tingkat dasar (Ula) sejauh ini memiliki karakter unik dan desain tersendiri yang dalam pandangan teori formal tentang pengelolaan pembelajaran di bawah manajemen kelas masih terkesan tradisional dan sederhana yang belum sepenuhnya memenuhi ketentuan pelaksanaan proses pembelajaran yang ideal seperti pada pembelajaran di lembaga-lembaga pendidikan formal lainnya, namun uniknya, proses pembelajaran tersebut berjalan dengan sangat khidmat, bahkan dalam pandangan sepintas banyak sekali capaian pembelajaran yang diperoleh oleh santri mengenai materi yang disampaikan guru melalui pembelajaran kitab kuning tersebut sekalipun dalam pandangan teori manajemen kelas itu masih sangat jauh dari kata ideal Maimun (2006). Fenomena inilah yang kemudian menarik untuk dilihat dalam perspektif yang lebih mendalam tentang bagaimana proses pelaksanaan pembelajaran di pesantren jika ditinjau dari sudut pandang teori formal manajemen kelas.

Metode pembelajaran kitab kuning yang lazim dipakai di pesantrendari dulu hingga sekarang di antaranya adalah metode sorogan, wetonan dan bandongan. Metode sorogan adalah proses pembelajaran dmana santri satu per satu secara bergiliran menghadap kiai dengan membawa kitab tertentu. Kiai membacakan beberapa baris dari kitab itu dan maknanya, kemudian santri mengulangi bacaan kiainya.Sedangkan, metode bandongan adalah metode mengajar dengan sistem ceramah, kiai membacakan kitab, menerjemahkan dan menjelaskan kalimat-kalimat yang sulit dari suatu kitab, sedangkan santri menyimak dan membuat catatan di pinggir kitab Ghafur (2005). Minimnya metode pembelajaran yang dipraktikkan Kiai di dalam pembelajaran kitab tanpa harakat di pesantren tersebut tidak membuat proses pembelajaran kitab kuning mengalami kendala yang berarti, tidak ada reaksi berlebih dari santri yang dapat mengganggu jalannya proses pembelajaran. Hal itu kemungkinan disebabkan oleh anggapan santri bahwa figur seorang Kiai adalah sosok yang harus selalu dihormati dan dipatuhi, hal ini senada dengan apa yang dikatakan oleh Nurcholis Madjid bahwa, 
keberadaan seorang kiai dalam lingkungan pesantren laksana jantung bagi kehidupan manusia. Intensitas kiai memperlihatkan peran yang otoriter disebabkan karena kiai adalah perintis, pendiri, pengelola, pengasuh, pemimpin, dan bahkan juga pemiliki tunggal sebuah pesantren Madjid (2012) . Selain itu, Bruinessen mengungkapkan adanya keyakinan dari kiai, guru, ataupun santri bahwa kitab gundul yang biasanya berwarna kuning merupakan teks klasik yang ada dan selalu diberikan di pesantren sebagai al-kutub mu'tabarah, yaitu suatu ilmu yang dianggap sudah bulat, tidak bisa dirubahubah, dan hanya bisa diperjelas dan dirumuskan kembali manakala kiai atau guru menghendaki Bruinessen (2010) .

Pesantren memiliki akar budaya yang kuat dalam kehidupan masyarakat Indonesia, terutama bagi masyarakat Islam. Tradisi pembelajaran kitab kuning merupakan ciri dan identitas yang hampir tidak dapat dilepaskan. Adanya pembelajaran kitab kuning pula, yang menjadikan pembeda antara pondok pesantren dengan lembaga pendidikan lain. Selain sebagai pedoman bagi tata cara keberagaman, kitab kuning juga difungsikan oleh kalangan pesantren sebagai referensi (maraji) universal dalam menyikapi segala tantangan kehidupan. Jadi, kitab kuning bukan hanya membahas ilmu-ilmu agama Islam seperti fiqih, aqidah, akhlaq, dan tarikh, tetapi juga membahas ilmu-ilmu lain, seperti sosial, ekonomi, dan kemasyarakatan yang digunakan dalam kehidupan sehari-hari. Dengan demikian penting untuk mengungkap secara ilmiah teori-teori manajemen kelas ala pembelajaran di pesantren sebagai upaya untuk memberikan kontribusi penting dalam menjaga eksistensi dan keunikan pembelajaran yang ada di dalam pesantren.

Manajemen kelas merupakan salah satu faktor penunjang keberhasilan proses pembelajaran, dikatakan demikian karena menajemen kelas mengatur, menciptakan dan mempertahankan suasana kelas secara optimal supaya kegiatan belajar mengajar dapat berjalan dengan efektif. Guru sebagai seorang yang memfasilitasi proses pembelajaran di kelas senantiasa memperhatikan bagaimana cara mengelola kelas dengan baik agar pembelajaran dapat berjalan efektif dan tujuan pembelajaran dapat tercapai. Manajemen kelas adalah tahap-tahap dan prosedur untuk menciptakan dan mempertahankan lingkungan belajar dan pembelajaran yang kondusif Ekosiswoyo (2006). Pengelolaan kelas yang efektif merupakan prasyarat mutlak bagi terjadinya proses pembelajaran yang efektif. Pengelolaan dipandang sebagai salah satu aspek penyelenggaraan sistem pembelajaran yang mendasar, diantara sekian macam tugas guru di dalam kelas Usman (2003) . Paul R. Burden and David M. Byrd, mengungkapkan bahwa:

"Classroom Management refers to the action and strategies teacher use to maintain order in classroom. Classroom management focuses on ways to establish and maintain workable system for classroom groups, rather than on ways to spot and punish misbehavior disorders, or capture the attention of individual student. Order mean that students are performing eithin acceptable limits the actions necessary for a particular classroom event to be successful." Burden et al. (1999)
Pentingnya manajemen kelas yang baik dapat merealisasikan tujuan pendidikan yang telah ditetapkan. Mengajar dan belajar adalah merangkul semua kegiatan seperti menulis di papan tulis, berdiskusi dengan siswa, mendemonstrasikan sebuah prosedur, mengawasi pekerjaan kelas siswa, membaca dan memberikan tugas. Lingkungan kelas yang baik dengan meja dan kursi yang baik, ruang yang berventilasi baik, pencahayaan yang baik, langit-langit dan atap yang baik dan lantai yang halus meningkatkan pengajaran dan pembelajaran yang efektif. Ketika lingkungan kelas memberikan siswa apa yang mereka butuhkan, keseimbangan terjadi tetapi ketika lingkungan kelas tidak, ada ketidakseimbangan Igbinoba (2015). Burden and Byrd mengungkapkan bahwa manajemen Kelas mengacu pada tindakan dan strategi yang digunakan guru untuk menjaga ketertiban di kelas. Manajemen kelas berfokus pada cara-cara untuk membangun dan memelihara sistem yang dapat diterapkan untuk kelompok-kelompok kelas, daripada pada cara-cara untuk menemukan dan menghukum gangguan perilaku buruk, atau menarik perhatian siswa secara individu. Urutan berarti bahwa siswa melakukan dalam batas yang dapat diterima tindakan yang diperlukan untuk acara kelas tertentu untuk menjadi sukses Burden and Byrd (2009) .

Manajemen kelas merupakan kegiatan multi faceted dan melampaui teknik manajemen perilaku tradisional yang direkomendasikan untuk mencegah perilaku siswa yang mengganggu. Guru harus mengembangkan hubungan yang peduli dan suportif dengan siswa; mengatur dan mengimplementasikan instruksi dengan cara mengoptimalkan akses siswa dalam belajar; dapat menggunakan metode manajemen kelompok yang mendorong keterlibatan siswa dengan tugas akademik mempromosikan pengembangan keterampilan sosial dan pengaturan diri siswa; dan menggunakan intervensi yang sesuai untuk membantu siswa yang memiliki masalah perilaku Chandra (2015) . Manajemen kelas menunjuk pada kegiatan yang menciptakan dan mempertahankan kondisi yang optimal bagi terjadinya proses pembelajaran Darmawan (2012) . Jadi, bisa dikatakan manajemen pembelajaran atau manajemen kelas adalah proses pengelolaan dalam kegiatan belajar mengajar yang dimulai dari proses perencanaan, pengorganisasian, pelaksanaan, pengendalian dan penilaian dalam rangka mencapai tujuan pedidikan.

Seperti hasil penelitian yang dilakukan oleh Shakti Sharma yang menunjukkan bahwa beberapabentuk intervensi dalam manajemen kelas membuat dampak positif pada guru, siswa, dan iklim sekolah secara keseluruhan.Guru perlu menjalin komunikasi secara pribadi dengan setiap siswa di kelas untuk membuat mereka merasa nyaman dan dihargai Sharma (2017) .Venkat Laksmi juga mengungkapkan, manajemen kelasmerupakan tanggung jawab gurudantugasnya adalah untuk memastikan bahwa pengelolaan kelas dapat diterapkan secara efektif.Dengan membangun hubungan positif,dengan membuat proses pembelajaran menarik, manifestasi kehangatan dan keramahan, memahami masalah dan kekurangan anak-anak yang mengalami gangguan dan praktik sistem penguatan akan membantu dalam mewujudkan atribut yang diinginkan pada 
guru umum untuk membangun lingkungan kelas yang kondusif Lakshmi (2017).

Dengan demikian, keberhasilan pendidikan dapat dilihat dari proses pembelajaran yang berlangsung, bagaimana guru mampu membangun manajemen kelas dengan baik agar proses pembelajaran berjalan efektif, dan mampu mewujudkan tujuan pendidikan yang ingin dicapai. Selain penggunaan strategi secara tepat, guru juga dituntut mampu untuk menggunakan dan memanfaatkan sumber daya yang ada, karena membangun manajemen kelas tidak hanya pada penggunaan strategi saja, akan tetapi bagaimana menjadikan manajemen kelas dapat bersinergi dengan semua potensi yang ada, baik dari karakteristik pendidik, peserta didik, pemanfaatan media belajar, sarana dan prasarana yang sudah tersedia maupun lingkungan yang mempengaruhi keberhasilan proses pembelajaran.

Dari pemaparan di atas, ada keinginan besar dari penulis untuk mengungkap lebih jauh tentang keunikan pelaksanaan pembelajaran di pesantren terutama tentang manajemen kelas dalam pembelajaran kitab kuning dan implikasinya yang sejauh ini telah diakui kualitasnya melalui peran lulusanlulusan yang banyak tersebar di masyarakat. Selain itu proses pembelajaran kitab kuning di pesantren juga memiliki keunikan tersendiri, yakni ada katimpangan antara pelaksanaan pembelajaran kitab kuning di pesantren jika ditnjau dari sudut pandang teori manajemen kelas, namun demikian, dalam kenyataannya santri sebagai objek belajar mampu mengalami proses belajar yang baik dalam pembelajaran tersebut, sebagian besar santri mampu memahami maksud dan tujuan pembelajaran yang disampaikan oleh Kiai atau Guru, yang jika ditinjau dari teori manajemen kelas hal itu kemungkinan sulit tercapai.

Penelitian ini dilakukan di Pesantren As-Sunniyah Kencong dan Pesantren Baitul Arqom Balung Kabupaten Jember. Dua pesantren tersebut memiliki karakteristik pembelajaran yang berbeda jika dilihat dari orientasi proses dan output pembelajaran yang dilaksanakn, Pesantren As-Sunniyah Kencong lebih berorientasi pada pesantren salaf sedangkan Pesantren Baitul Arqom lebih berorientasi pada muadalah, perbedaan itulah yang menjadi alasan penulis untuk menjadikan kedua pesantren tersebut sebagai tempat penelitian untuk melihat lebih mendalam tentang praktik manajemen kelas khas pesantren khusus dalam pembelajaran kitab kuning. Selain itu, belajar kitab kuning sejauh ini masih dianggap sebagai sesuatu yang sulit dipelajari, untuk itu penulis ingin mengetahui bagaimana manajemen kelas khas pesantren dalam mendukung ketercapaian tujuan pembelajaran kitab kuning di kedua pesantren tersebut. Penelitian ini difokuskan pada pembelajaran kitab kuning di tingkat Madrasah Diniyah 'Ula karena dianggap lebih representatif dalam mengungkap keunikan-keunikan yang dipraktikkan dalam proses pembelajaran perspektif manajemen kelas.

\section{METODE}

Penelitian ini adalah penelitian kualitatif dengan menggunakan pendekatan fenomenologis. Penelitian fenomenologi ini melakukan pengujian dengan deskripsi dan refleksi terhadap setiap hal yang penting terutama dari fenomena yang given Smith and Shinebourne (2009). Ada beberapa ciri-ciri pokok fenomenologis yang dilakukan oleh peneliti fenomenologis yaitu: (1) mengacu kepada kenyataan, dalam hal ini kesadaran tentang sesuatu benda secara jelas, (2) memahami arti peristiwa dan kaitan-kaitannya terhadap orang-orang yang berada dalam situasi-situasi tertentu, (3) memulai dengan diam Moleong (2010). Setiap orang akan melihat realita yang berbeda pada situasi yang berbeda dan waktu yang bebeda. Sebagai contoh perasaan (feeling) pada pagi ini akan berbeda pada pagi besok. Sehingga ketika peneliti melakukan wawancara kepada seseorang pada pagi hari akan berbeda pada pagi lainnya. Sehinga jarak, waktu, hubungan manusia, tempat tinggal akan mempengaruhi setiap pengalaman manusia. Maka peneliti berusaha memahami arti peristiwa dan kaitankaitannya terhadap orang-orang yang berada dalam situasisituasi tertentu.

Dalam penelitian ini teknik penentuan subyek penelitian yang digunakan dengan cara purposive. Teknik Purposive adalah teknik pengambilan subyek penelitian (informan) dengan pertimbangan tertentu Sugiyono (2012) . Pertimbangan tersebut yaitu subyek penelitian yang memahami dan terlibat langsung terkait dengan manajemen kelas di Pondok Pesantren As-Sunniyah Kencong dan Pondok Pesantren Baitul Arqom Balung Jember. Hal ini dimaksudkan untuk memilih subyek penelitian yang benar-benar relevan dan kompeten dengan masalah penelitian sehingga data yang diperoleh valid dan dapat digunakan untuk membangun teori. Adapun teknik pengumpulan data yang dilakukan dalam penelitian ini menggunakan instrumen wawancara, observasi, dan studi dokumenter. Dalam analisis data kualitatif terdapat tiga alur kegiatan yang terjadi secara bersamaan. Aktivitas dalam analisis data yaitu: Data Condensation, Data Display, dan Conclusion Drawing/Verifications Miles et al. (2014) . Pengecakan keabsahan data adalah bagian yang sangat penting dan tidak terpisahkan dari penelitian kualitatif. pelaksanaan pengecekan keabsahan data didasarkan pada empat kriteria yaitu derajat kepercayaan (credibility), keteralihan (transferability), kebergantungan (dependability) dan kepastian (confirmability) (Creswell, 2002).

\section{HASIL DAN PEMBAHASAN}

Pesantren As-Sunniyah Kecong dan Baitul Arqom Balung Kabupaten Jember sudah memiliki tujuan dan target yang spesifik dalam membentuk output, di antaranya ingin menciptakan lulusan yang mampu menguasai ilmu agama dengan baik. Kedua pesantren tersebut meiliki karakter tersendiri dalam pelaksanaan manajemen kelas dalam pembelajaran 
kitab kuning yang tidak ditemui pada lembaga atau institusi lain di luar pesantren. Namun demikian kedua pesantren tersebut telah mampu meluluskan para alumni yang mampu menguasai ilmu keagamaan dengan baik dengan salah satu perantaranya melalui pembelajaran kitab kuning. Hal ini dapat dijadikan acuan bahwa dalam proses pembelajaran kitab kuning diyakini mampu membentuk intelektualitas santri dalam belajar khususnya penguasaan dalam hal keagamaan melalui pembelajaran kitab kuning.

Kondisi pesantren yang sederhana dapat dilihat dari segi fisik bangunan, metode, bahan kajian dan perangkat belajar lainnya. Pesantren merupakan lembaga pendidikan yang unik, khususnya dalam hal penyelenggaraan pendidikan non formal di Indonesia. Hal itu dilatarbelakangi oleh kondisi pesantren yang merupakan bagian penting di masyarakat, masyarakat merasa memiliki pesantren dengan segala keterbatasannya, rasa peduli yang tinggi terhadap kemandirian pesantren menjadikan pesantren tidak mudah lekang oleh tuntutan zaman. Begitu pula dalam hal pembelajaran, pesantren mampu menampilkan dirinya sebagai lembaga pendidikan yang tidak berorientasi profit, melainkan bentuk penyaluran dakwah dalm memberi edukasi kepada masyarakat tentang agama. Selain pembelajarannya, yang menjadi ciri khas dari pesantren adalah rasa keikhlasan yang dimiliki para santri dan kyai. Hubungan mereka tidak hanya sekedar sebagai murid dan guru, tapi lebih seperti anak dan orang tua. Tidak heran bila santri merasa kerasan tinggal di pesantren walau dengan segala kesederhanaannya. Bentuk keikhlasan itu terlihat dengan tidak dipungutnya sejumlah bayaran tertentu dari para santri, mereka bersama-sama bertani atau berdagang dan hasilnya dipergunakan untuk kebutuhan hidup mereka dan pembiayaan fisik lembaga, seperti lampu, bangku belajar, tinta, tikar dan lain sebagainya.

Materi yang dikaji dalam pembelajaran kitab kuning di pesantren adalah ilmu-ilmu agama, seperti fiqih, nahwu, tafsir, tauhid, hadist dan lain-lain. Kitab tersebut dikenal juga dengan kitab turost. Di antara kajian yang ada, materi nahwu dan fiqih mendapat porsi mayoritas. Ha litu karena mereka memandang bahwa ilmu nahwu adalah ilmu kunci. Seseorang tidak dapat membaca kitab kuning bila belum menguasai nahwu. Sedangkan materi fiqih karena dipandang sebagai ilmu yang banyak berhubungan dengan kebutuhan masyarakat (sosiologi). Tidak heran bila sebagian pakar meneybut sistem pendidikan Islam pada pesantren dahulu bersifat "fiqih orientied" atau "nahwu orientied". Masa pendidikan tidak tertentu, yaitu sesuai dengan keinginan santri atau keputusan sang Kyai bila dipandang santri telah cukup menempuh studi padanya. Biasanya sang Kyai menganjurkan santri tersebut untuk nyantri di tempat lain atau mengamalkan ilmunya di daerah masing-masing. Para santri yang tekun biasanya diberi "ijazah" dari sang Kyai.

Di pesantren As-Sunniyah Kencong Jember sebagai pesantren salaf yang semua pembelajaran berbasis kitab kuning adalah proses staandarisasi ketuntasan belajar santri dalam penguasaan kitab kuning. Sebagian besar santri mengikuti pembelajaran kitab kuning dengan menggunakan metode ban- dongan, yakni mengikuti pembelajaran kitab kuning dengan menyimak secara bersama-sama materi yang disampaikan kyai yang secara kemampuan bisa saja akan berbeda satu santri dengan santri yang lain. Di Pesantren As-Sunniyah Kencong proses pembelajaran tidak diisi dengan tanya jawab. Apapun hal yang menjadi penjelasan kyai itu menjadi sumber pengetahuan bagi seluruh santri peserta pengajian kitab kuning. Berbeda dengan Pesantren As-Sunniyah Kencong, Pesantren Baitul Arqom Balung Jember, yang merupakan representasi dari pesantren modern, permasalahan berkisar pada materi yang diajarkan sangat padat yakni ada materi khusus pondok pesantren, materi madrasah diniyah, dan madrasah formal. Padahal waktu yang tersedia kurang cukup memadai untuk menyampaikan materi itu, sehingga banyak santri yang masih kurang mampu membagi waktu dan berim likasi pada kurangnya pemahaman terhadap materi yang diajarkan. agi santri yang masih baru masuk di pesantren ini merasa sangat susah sekali dalam memahami materi pondok pesantren, selain materinya padat, juga dalam bahasa Arab dan tulisannya pun tulisan Arab, karena banyak yang baru di sini mendapat pelajaran tersebut.

Pesantren As-Sunniyah dan Pesantren Baitul Arqom merupakan lembaga pendidikan Islam yang tetap melestarikan dan menyelenggarakan pembelajaran kitab kuning serta telah terbukti melaksanakan pembelajaran kitab kuning dengan baik hal itu tercermin dari kualitas para lulusannya. Dengan demikian, kedua pesantren ini diharapkan memberikan kontribusi besar dalam menciptakan generasi muda Islam yang mampu menguasai kitab kuning dengan baik melalui pelaksanaan pembelajaran yang baik khas pesantren. Kedua pesantren tersebut melaksanakan manajemen kelas yang khas dalam proses pembelajaran kitab kuning yang jika dibandingkan dengan teori manajemen kelas akan ditemukan beberapa perbedaan. Karena hal itulah maka komponen-komponen manajemen kelas yang ada di pesantren tersebut tidak sejalan dengan teori manajemen kelas yang banyak dilaksanakan di lembaga lain pada umumnya. Namun di sisi yang lain kedua pesantren tersebut mampu menghadirkan lulusan yang mumpuni dan kompeten terutama dalam penguasaan masalah-masalah keislaman yang banyak dibutuhkan oleh masyarakat seperti banyaknya lulusan Pesantren As-Sunniyah dan Baitul Arqom yang menjadi mubaligh maupun pengajar kitab kuning yang tersebar di masyarakat.

Jauh sebelum para pakar modern berfikir bagaimana pengelolaan kelas secara lebih baik, pesantren sudah menyuguhkan pengelolaan kelas khas pesantren dengan segala keterbatasannya. Pesantren mampu memberikan dimensi baru tentang desain tempat terciptanya proses pembelajaran yang disebut kelas. Kelas di pesantren diartikan sebagai tempat di mana para santri atau siswa belajar tidak berbatas pada ruangan atau sekat tembok yang ada. dalam hal ini kelas dimaknai sebagai tempat terjadinya proses pembelajaran yang memungkin orang untuk belajar, jadi hal itu bisa terjadi di manapun. Di pesantren hal tersebut sudah dilakukan sejaka lama, kelas pesantren sangat terbatas jika hanya dikategorikan dalam 
ruang atau bangunan tembok. Kelas pembelajaran khususnya pembelajaran kitab kuning di pesantren banyak dilakukan di ruang-ruang terbuka bahkan di tempat yang tidak biasa seperti di masjid, halaman pondok, dalem kyai dan ruang-ruang lain yang memungkinkan untuk dilaksanakannya proses pembelajaran. jadi dalam hal ini, kelas pembelajaran bukan hanya suatu ruangan yang dibatasi oleh empat dinding (bentuknya segi empat) tempat di mana sejumlah santri/siswa berkumpul untuk mengikuti proses pembelajaran yang di dalamnya terdiri dari papan tulis, bangku atau tempat menulis serta saranasarana lain yang biasa ada di dalam kelas. Kelas dalam pengertian tradisional mengandung sifat statis, berdasar kebutuhan belajar pada saat itu. Pengelompokan kelas tradisional khususnya di pesantren banyak merujuk pada tingkat perkembangan santri khususnya dalam penguasaan kitab atau materi dimulai dari yang paling sederhana sampai pada yang paling rumit dalam hal pembahasannya. Selain itu pengelompokan kelas berikunya biasanya didasarkan pada batas umur santri, yakni usia santri dan lama santri berada di pesantren.

Dengan demikian, kelas memiliki arti yang lebih luas yaitu suatu masyarakat kecil yang merupakan bagian dari masyarakat sekolah/madrasah yang sebagai kesatuan dan diorganisir menjadi unit kerja secara dinamis untuk menyelenggarakan kegiatan-kegiatan pembelajaran yang kreatif untuk mencapai suatu tujuan pembelajaran. Jadi, yang dimaksud dengan kelas di sini bukan hanya kelas yang merupakan ruangan yang dibatasi dinding tempat para siswa berkumpul bersama untuk mempelajari segala yang disajikan oleh pengajar, tetapi lebih dari itu kelas merupakan satuan unit kecil siswa yang berinteraksi dengan guru dalam pembelajaran dengan beragam keunikan yang dimiliki. Seluruh aspek tersebut perlu ditanggapi secara positif sebagai faktor pemacu dalam mewujudkan situasi dinamis yang dapat berlangsung dalam kelas, sehingga segenap siswa diharapkan dapat tumbuh dan berkembang secara efektif dan terarah sesuai dengan tugastugas perkembangan mereka. Dan situasi seperti inilah yang akan mendorong terciptanya kerjasama sekaligus persaingan yang sportif dalam meraih prestasi belajar. Hubungan manusiawi yang efektif ini dapat menjadi motivator belajar siswa, dan merupakan faktor pendukung bagi penciptaan lingkungan yang kondusif bagi pelaksanaan proses belajar mengajar.

Hasil temuan penelitian menunjukkan bahwa pembelajaran kitab kuning pada tingkat dasar (Ula) di kedua pesantren tersebut, santri tidak langsung diajarkan kitab kuning, akan tetapi terlebih dahulu diajarkan cara membaca Aksara Pegon, sehingga para santri yang baru masuk dikondisikan sedemikian rupa agar lebih familier dengan Aksara Pegon (Pego). Secara etimologi, kata Pegon artinya tulisan atau huruf berbahasa Jawa yang ditulis dalam teks Arab (hijaiyah). Kata Pegon berasal dari bahasa Jawa, pego, yang memiliki arti "ora lumrah anggone ngucapake" (tidak lazim dalam mengucapkan) Kromoprawiro (1867). Maksudnya karena banyak kata Jawa yang jika ditulis dengan teks Arab menjadi agak aneh ketika diucapkan. Pigeaud mengungkapkan bahwa Bahasa Jawa yang ditulis dengan teks Arab disebut pegon, yang artinya "sesuatu yang berkesan menyimpang" Pudjiastuti (1994). Penamaan ini karena jika diparalelkan, jumlah teks Jawa lebih sedikit daripada teks Arab. Sastra suluk dan pensyarahan kitab kuning melalui cara nadhoman, terjemahan nadhoman, terjemahan jenggotan, maupun jenis sastra berbentuk syi iran, pada dasarnya semua itu ditulis menggunakan tulisan Pegon Fauzan (2014) . erlu diketahui bahwa egon mengenal dua macam variasi, yakni Pegon Berharakat dan Pegon Gundhul (tidak berharakat).

Alasan mengapa tingkat dasar (Ula) di kedua pesantren perlu ditekankan pemahaman Aksara Pegon? Asumsi yang digunakan adalah dengan keterampilan dan pemahaman dalam hal baca dan tulis Aksara Pegon, menjadikan para santri agar lebih siap dan mudah untuk mempelajari kitab-kitab kuning dengan berbagai jenisnya nanti. Pembelajaran baca tulis Aksara Pegon dikaitkan juga dengan kehidupan sehari-hari santri, agar penguatan basic study Kitab Kuning pada tingkat dasar ini menjadi modal utama menuju ke jenjang yang lebih tinggi. Setelah menguasai baca tulis Aksara Pegon, maka selanjutnya santri diperkenalkan dengan pelajaran tangga ibadah, pegon tingkat Advance, dan baca tulis Alquran, baru kemudian penguatan dan pengenalan langsung pada kitab-kitab kuning.

Pembelajaran Kitab Kuning tingkat dasar (Ula) di kedua pesantren tersebut sesungguhnya merupakan kelas yang luas dan hiperkomplek, mengapa demikian?, sebab bila ditinjau dari pola pembelajaran keilmuan yang diterima oleh para santrinya dilakukan secara terus-menerus 24 jam, yaitu sejak para santri bangun tidur hingga tidur kembali semuanya sarat dengan pembelajaran dan hikmah. Oleh karena itulah bila ditinjau dari pengertian manajemen kelas secara modern pesantren secara keseluruhan merupakan kelas yang besar, dimana seluruh komponen pesantren yang ada merupakan hal yang sengaja dihadirkan dalam mensukseskan tujuan pembelajaran pesantren: Pertama; ruang pesantren merupakan sebuah ruang kelas besar yang telah didesain sedemikian khas berasaskan simbol kearifan lokal pesantren guna membentuk lingkungan pembelajaran yang berakhlaq mulia berdasarkan tuntutan agama kedua, harmonisasi sosio-emosianal antara guru besar (kyai) dengan guru guru kecil (ustadz / santri senior) dengan para santri umumnya terjalin sangat sangat erat yang membentuk hirarki sub kultur yang khas ala santri dengan kiainya. $K$ etiga, di dalam kelas besar esantren tersebut sekelompok masyarakat belajar telah sedang diorganisir secara tradisional, bahkan hingga santri tersebut menjadi alumni sekalipun akan terus menerus berada dalam orbit organisasi ini dengan kebanggan yang mendalam pada guru dan almamaternya.

Manajemen kelas yang dimaksud dalam penelitian ini yaitu upaya memberdayagunakan seluruh potensi kelas, baik sebagai komponen utama pembelajaran maupun komponen pendukung digunakan seoptimal mungkin untuk mendukung proses interaksi edukatif mencapai tujuan pembelajaran. Prosedur manajemen kelas diterapkan pada rancangan pengelolaan kelas dimensi pencegahan (preventif), dan rancangan prosedur pengelolaan kelas yang dimensi penanganan 
(kuratif) Atkinson (2001). Perbedaan kedua jenis pengelolaan kelas tersebut, akan berpengaruh terhadap perbedaan langkahlangkah yang perlu dilakukan oleh seorang guru dalam menerapkan kedua jenis manajemen kelas tersebut. Dikatakan secara preventif apabila upaya yang dilakukan atas dasar inisiatif guru untuk menciptakan suatu kondisi dari kondisi interaksi biasa menjadi interaksi pendidikan dengan jalan menciptakan kondisi baru yang menguntungkan bagi pembelajaran. Sedangkan yang dimaksud dengan manajemen kelas secara kuratif adalah yang dilaksanakan karena terjadi penyimpangan pada tingkah laku siswa, sehingga mengganggu jalannya pembelajaran.

Hal itu juga senada dengan yang diungkapkan oleh AkinLittle (2017), Aliakbari and Heidarzadi (2015), Demir (2012) , manajemen kelas mencakup prosedur proaktif dan reaktif yang bertujuan untuk menciptakan lingkungan belajar yang menarik, memfasilitasi siswa, menciptakan perhatian dan partisipasi. Untuk mencapai partisipasi aktif siswa, para guru mengembangkan rutinitas kelas, mendorong siswa untuk berpartisipasi dalam kegiatan belajar dan mengutamakan belajar kooperatif. Hasilnya, perilaku negatif siswa dapat dicegah melalui keterlibatan dan komitmen pribadi dan kelompok, sehingga motivasi siswa, kinerja akademik dan hasil belajar dapat meningkat dalam lingkungan belajar yang aman, variatif, dan profesional Koutrouba et al. (2018)

Dalam manajemen kelas dikenal tiga pilar utama, yaitu: pendekatan pengubah tingkah laku, pendekatan sosioemosional, dan pendekatan proses kelompok dalam belajar Guskey and Huberman (1995) . Pertama, pendekatan pengubahan tingkah laku, yang menganggap bahwa semua tingkah laku merupakan hasil belajar, serta setiap individu perlu diperhitungkan dalam proses pembelajaran. Prinsip tersebut yaitu berupa adanya tindakan penguatan positif dan negatif, yaitu memberikan stimulus positif terhadap perilaku yang memang diharapkan, dan memberikan penghukuman atau tidak memberikan ganjaran atau meniadakan perangsang yang tidak menyenangkan atau tidak disukai. Kedua, pendekatan sosio-emosional, yang bertolak dari asumsi bahwa proses pembelajaran yang efektif mempersyaratkan adanya iklim sosioemosional yang baik, serta guru menduduki posisi terpenting bagi terbentuknya iklim sosioemosional yang baik itu. Ketiga, pendekatan proses kelompok, yang bertolak dari asumsi bahwa pengalaman belajar berlangsung dalam suasana kelompok, serta tugas guru yang terutama dalam pengelolaan kelas adalah membina dan memelihara kelompok yang efektif dan produktif.

Pendekatan perubahan perilaku yang ditemukan pada Pembelajaran Kitab Kuning pada tingkat dasar (Ula) di pesantren As-Sunniyah dan pesantren Baitul Arqom bahwa kondusifitas kelas karena dilandasi unsur spiritualitas yakni ngalap barokah (mencari berkah) seorang kiai atau guru. Dinamika pembelajaran telah membuat pesantren sadar dan melakukan serangkaian rasionalisasi normatif dalam ruang sub kulturnya, hal ini salah satunya adalah membuat suatu penguatan hegemony positif tahapan tahapan pencapaian pembelajaran yang ada didalamnya. Dia taranya adalah kontestasi narasi barokah dan kuwalat yang diahdirkan secara bersamaan sebagai penguatan primer untuk melakukan upaya motivatif terhadap proses belajar sebagai sesuatu yang mendatangkan erkah (barokah), dan sebaliknya upaya pengutan antisipatif atas proses belajar yang cenderung negatif diberikanya sebauh imbol keresahan masa depan yang berupa kutukan (kualat atau cangkolang) Fatah and M (2015) . Dari sinilah behavior $m$ odification pesantren dikukuhkan, dengan kesadaran penuh bahwa pesantren merupakan kelas besar yang terus-menerus dikelola, agar media pembelajaran sekaligus sumber belajar yang ada dikelas besar tersebut terusmenerus efektif.

Pendekatan sosio-emotional di kedua pesantren tersebut tampak dari pola interaksi antara kiai, guru, dan santri, yang berada dalam satu kompleks pesantren ibarat keluarga besar, sehingga dalam proses pembelajaran Kitab Kuning kiai dan guru memiliki persepsi sebagai orangtua, sedangkan santri sebagai anak. Hubungan Kiai dan guru dengan santri yang penuh simpati dan saling menerima merupakan kunci pelaksanaan dari pendekatan ini. Dengan demikian, pendekatan ini menekankan pentingnya tingkah laku atau tindakan Kiai yang menyebabkan santri memandang Kiai itu benar-benar terlibat dalam pembinaan santri dan memperhatikan apa yang dialami santri baik suka maupun duka. Dalam pesantren, pendekatan emosiaonal santri yang dikukuhkan secara teologis melalui kiriman doa kiai kepada santrinya, sebaliknya santri pun memiliki keyakinan akan mendapatkan tujuan belajar salah satunya melalui doa tawasul kepada rantai sanat para guru-gurunya, disatu sisi kedekatan emsosional juga dibangun dalam ruang keakraban wali santri dengan kiainya, setidaknya ketika santri masuk pesantren sang wali santri harus terlebih dahulu melakukan dialog dari hati kehati dengan para kiai calon pembimbing anaknya, melalui serangakian seremoni "memasrahkan anak ke kiai." Alhasil, akan tercipta situasi yang komunikatif di samping adanya hubungan timbal balik antara Kiai dan santri, dan antara santri dengan santri. Dhofir mengatakan bahwa adanya sikap timbal balik antara Kiai dan santri di mana para santri menganggap Kyai seolah-olah menjadi bapaknya sendiri, sedangkan santri dianggap Kyai sebagai titipan Tuhan yang harus senantiasa dilindungi Dhofier (2011)

Pendekatan proses kelompok di pesantren tampak dari kekompakan para santri dalam kegiatan belajar bersama serta keyakinan bahwa belajar berlangsung sepanjang hayat dan dimana saja. Pesantren merupakan organisasi pendidikan yang paling solid dari sisi loyalitas para santri terhadap almamater dimana peserta didik menimba ilmu, kolektifitas ini terpelihara melalui jalinan silaturahim lahir dan batin antara guru dan santri, santri dengan santri, santri dengan masyarakat. Dalam pesantren pola ini sangat terjaga, sehingga kelak ketika sudah dinyatakan alumni dari suatu pesantren tertentu, sang santri akan terus ikut serta dalam ajang silaturahim alumni. Sebagaimana pesantren As-Sunniyah dan Baitul Arqom, kedua pesantren tersebut memafaatkan jaringan para alumninya. Hal yang bisa digaris bawahi bahwa pembelajaran santri tidak berhenti pada saat santri telah dinyatakan boyong (keluar 
dari pesantren tersebut), tetapi proses komunikasi dengan pesantren tidak lantas kemudian terputus, tetapi kepengasuhan kiai bersambung sepanjang hayat alumninya, inilah group proc es yang sesungguhnya yang terus tersambung dan terkawal melalui rangkaian sanat kiai dan santri. Haedari mengatakan, eksistensi pesantren di Indonesia dimulai sejak Islam masuk negeri ini dengan mengadopsi sistem pendidikan keagamaan yang sebenarnya telah lama berkembang sebelum kedatangan Islam. Dengan adanya kekuatan relasional santri dan kiainya, tidak heran lembaga pendidikan ini mampu berurat akar di negeri ini, bahkan pesantren diakui memiliki andil yang sangat besar terhadap perjalanan sejarah bangsa Haedari (2007) .

Berdasarkan hasil penelitian dan pembelajaran yang telah dipaparkan tersebut maka dapat disusun sebuah pola sebagai berikut.

Metode dalam pembelajaran Kitab Kuning pada tingkat dasar (Ula) di pesantren As-Sunniyah dan Baitul Arqom didominasi dengan metode wetonan atau bandongan dan metode sorogan, selain itu juga diterapkan metode diskusi (munazharah) dan metode hafalan. Metode pembelajaran tersebut disesuiakan dengan materi, dalam arti menyesuaikan dengan bentuk dan coraknya, sehingga metode mengalami transformasi bila materi yang disampaikan berubah. Metode wetonan atau bandongan adalah cara penyampaian kitab dimana seorang guru, kiai, atau guru membacakan dan menjelaskan isi kitab, sementara santri, murid, atau siswa mendengarkan, memberikan makna, dan menerima Siradj (2008) . Dalam metode ini kiai atau guru hanya membaca salah satu bagian dari sebuah bab dalam sebuah kitab, menerjemahkannya ke dalam bahasa Jawa atau Indonesia dan memberikan penjelasan-penjelasan yang diperlukan Turmudi (2009) . Namun, penulis menemukan kelemahan dari metode wetonan atau bandongan diantaranya metode ini membuat para santri lebih bersikap pasif, sebab dalam kegiatan pembelajarannya kiai, guru lebih mendominasi, sedangkan santri lebih banyak mendengarkan dan memperhatikan keterangan yang disampaikan oleh guru. Akan tetapi efektifitas metode ini terletak pada pencapaian kuantitas dan percepatan kajian kitab, selain juga untuk tujuan kedekatan relasi santri-kiai, guru.

Penerapan metode sorogan yakni santri satu per satu secara bergiliran menghadap kiai atau guru dengan membawa kitab tertentu. Kiai atau guru membacakan beberapa baris dari kitab itu dan maknanya, kemudian santri mengulangi bacaan kiainya. Dengan kata lain, santri yang membaca sedangkan guru mendengarkan sambil memberi catatan, komentar, atau bimbingan bila diperlukan. Akan tetapi dalam metode ini, dialog santri dan guru belum atau tidak terjadi Siradj (2008). Qamar menyatakan bahwa ada beberapa kelebihan dari metode sorogan yang secara didaktik-metodik terbukti memiliki efektivitas dan signifikansi yang tinggi dalam mencapai hasil belajar. Sebab metode ini memungkinkan kiai, guru mengawasi, menilai, dan membimbing secara maksimal kemampuan santri dalam penguasaan materi Qamar (2011) .

Metode diskusi (munazharah atau musyawarah) yakni sekelompok santri tertentu membahas permasalahan, baik yang diberikan kiai maupun masalah yang benar-benar terjadi dalam masyarakat. Diskusi ini dipimpin oleh seorang santri dengan pengamatan dari guru yang mengoreksi hasil diskusi itu. Metode diskusi bertujuan untuk merangsang pemikiran serta berbagai jenis pandangan agar santri aktif dalam belajar. Melalui metode ini, akan tumbuh dan berkembang pemikiran-pemikiran kritis, analitis, dan logis, dan akan lebih memicu para santri untuk menelaah atas kitab-kitab yang lain. Keberhasilan yang dicapai ditentukan oleh tiga unsur yaitu pemahaman, kepercayaan diri, dan rasa saling menghormati Muhaimin (2006) . Sedangkan, metode hafalan merupakan metode unggulan dan sekaligus menjadi ciri khas yang melekat pada sebuah pesantren sejak dahulu hingga sekarang. Metode hafalan ini masih tetap dipertahankan sepanjang masih berkaitan dan diperlukan bagi argumen-argumen naqly dan kaidah-kaidah. Dan metode ini biasanya diberikan kepada anak-anak yang berada pada usia sekolah tingkat dasar atau tingkat menengah. Sebaliknya, pada usia-usia di atas itu sebaiknya metode ini dikurangi sedikit demi sedikit dan digunakan untuk rumus-rumus dan kaidah-kaidah.

Dengan demikian, manajemen kelasmerupakansalah satu bagian penting dalam proses pembelajaran, tidak terkecuali di lembagapesantren.Sebab kemampuan memberikan pelajaran saja tanpa dibarengi dengan kemampuan mengorganisir kelas,tidak akan memberi prestasi belajar seperti yang diharapkan. Manajemen kelas padapesantrenmenerapkan pola NaikKitab dan menjadikan kelasnya hanya sebagai tempat belajar.Pola ini bersifat sederhana di mana kelas berada di bawah tanggung jawab seorang ketua atau koordinator yang hanya memiliki tugas memegang absen hadir, dan mengurus hal-hal teknis lainnya terutama berhubungan dengan kelompok belajarnya.Kelas sebagai tempat belajar di pesantren tidak memiliki struktur formal seperti kelas di sekolah formal yang terlalu terikat dengan waktu dan bahan ajar.Selain mengajar, guru di pesantren jugaberperan sebagai pembimbing yang tidak terikat dengan waktu dan bahan ajar.Sesekali mereka mengontrol kelompok belajar yang dibimbingnya saat kelompok belajar tersebut diminta untuk mengulang pelajaran di luar jam yang ditentukan. Jadi, peran guru di pesantren tidak hanya mengajar, namun juga membimbing santri yang sedang belajar dengan melakukan banyak hal seperti meluruskan bacaan santri terhadap suatu kitab.Hal ini akan berbeda jika di bandingkan dengan sistem klasikal,selain santri naik kelas pada periode tertentu, pengelolaan kelas lebih komplek karena berada di bawah tanggung jawab wali kelas dan organisasi kelas. Implikasi dari pengelolaan kelas seperti ini adalah terciptanya kerja sama antara guru (terutama wali kelas) dengan santri. Kondisi ini sekaligus merupakan bentuk pengajaranterhadap santri untuk berorganisasi pada level kelas danmenanamkansense of responsibilityterhadap kelas yang ditempatinya. 


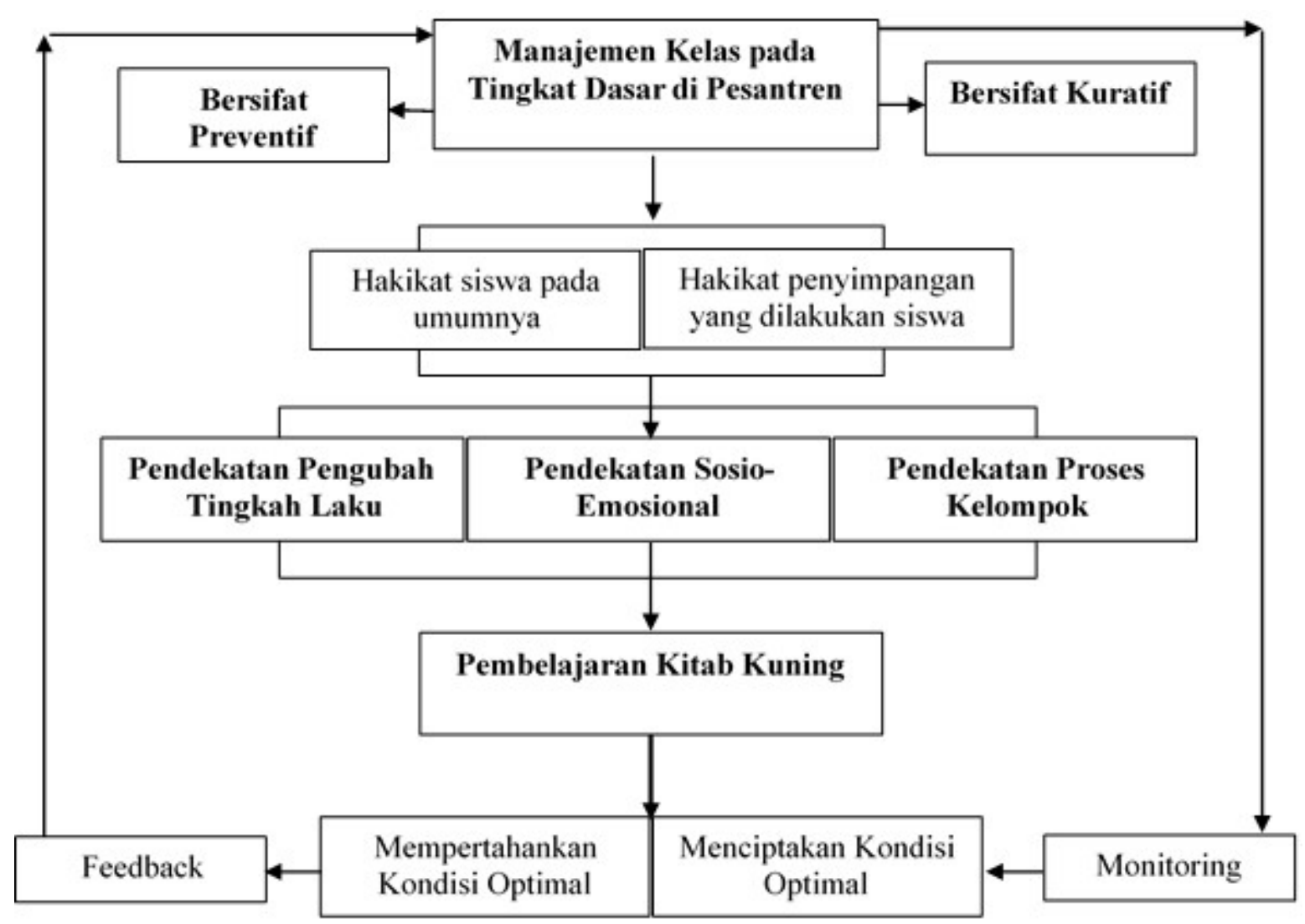

FIGURE 1 | Pola Manajemen Kelas Pembelajaran Kitab Kuning pada Tingkat Dasar di Pesantren

\section{KESIMPULAN}

Pesantren sebagai basis kelas pembelajaran tradisonal tidak melulu menampakan karakter tradisional semata, akan tetapi nilai nalai keraifan lokalitas pesantren yang setara dengan konsep pembelajaran modern telah ada dan dipraktikan oleh pelaku-pelaku pesantren, dalam hal pengelolaan kelas pembelajaran, pesantren tidak hanya memandang kelas dari sisi ruang yang sempit sebagaimana konsep pembellajaran klasikal modern, tetapi pesantren telah memberikan pemaknaan lebih bahwa pesantren itu sendirilah sebenarnya merupakan ruang kelas besar dimana upaya kiai melakukan pendekatan manajemen kelas berbasis spiritual.

Manajemenkelas pada pembelajaran Kitab Kuning pada Tingkat Dasar (Ula) di Pesantren As-Sunniyah Kencong dan Pesantren Baitul Arqom Balung Kabupaten Jember telah dirancang sesuai prinsip pencegahan (preventif), dan prinsip penan- ganan (kuratif).Dalam pelaksanaannya menggunakan pendekatan pengubah tingkah laku, sosio-emosional, danproses kelompokbelajar.Pendekatan perubahan perilaku yang ditemukan pada Pembelajaran Kitab Kuningbahwa kondusifitas kelas karena dilandasi unsur spiritualitas yakni ngalap barokah (mencari berkah) seorang kiai atau guru.Pendekatan sosioemotional tampak dari pola interaksi antara kiai, guru, dan santri, yang berada dalam satu kompleks pesantren ibarat keluarga besar. Sedangkan, pendekatan proses kelompok belajar di pesantren tampak dari kekompakan para santri dalam kegiatan belajar bersama serta keyakinan bahwa belajar berlangsung sepanjang hayat dan dimana saja. Adapun metode dalam pembelajaran Kitab Kuning di pesantrendidominasi dengan metode wetonan atau bandongan dan metode sorogan, selain itu juga diterapkan metode diskusi (munazharah) dan metode hafalan.

\section{REFERENCES}

Akin-Little, K. A. (2017). Teachers' Use of Classroom Management Procedures in the United States and Greece: A Cross-Cultural Comparison. School Psychology International, 53-62.

Aliakbari, M. and Heidarzadi, M. (2015). The relationship between EFL teachers

beliefs and actual practices of classroom management. Cogent Education 2, 113. doi: 10.1080/2331186x.2015.1039255.

Atkinson, R. L. (2001). Pengantar Psikologi Jilid II (Jakarta: Erlangga).

Bruinessen, M. V. (2010). Kitab Kuning, Pesantren dan Tarekat (Bandung: Mizan).

Burden, P. R. and Byrd, D. M. (2009). Methods For Effective Teaching (Needham Heights: Allyn and Bacon A Viacom Company). 
Burden, P. R., Byrd, D. M., and Byrd (1999). Methods For Effective Teaching (Needham Heights: Allyn and Bacon A Viacom Company).

Chandra, R. (2015). Classroom Management for Effective Teaching. International Journal of Education and Psychological Research 4, 13-15.

Darmawan, D. (2012). Komunikasi Pembelajaran (Bandung: PT. Remaja Rosdakarya).

Demir, M. K. (2012). Examination of Turkish Prospective Teachers' Attitudes and Beliefs Towards Classroom Management. The International Journal of Research in Teacher Education 3, 12-25.

Dhofier, Z. (2011). Tradisi Pesantren Studi tentang Pandangan Hidup Kyai (Jakarta: LP3S), 1-192.

Ekosiswoyo, R. (2006). Manajemen Kelas Suatu Upaya untuk Memperlancar Kegiatan Belajar (Semarang: IKIP Semarang Press).

Fatah, R. A. and M, T. (2015). Rekontruksi Pesantren Masa Depan (Jakarta: PT. Listafariska Putra).

Fauzan (2014). Ikhtisar Tata Bahasa Arab. Ikhtisar Tata Bahasa Arab. Diambil kembali dari Ikhtisar Tata Bahasa Arab, 0423.

Ghafur (2005). Potret Pendidikan Anak-anak Pengungsi (Sebuah Studi di Pesantren Zainul Hasan Probolinggo) (Malang: UIN Malang)

Guskey, T. R. and Huberman, L. (1995). Professional Development in Education: New Paradigms and Practices, Teachers College (New York: Columbia University).

Haedari, M. A. (2007). Transformasi Pesantren (Jakarta: Media Nusantara).

Igbinoba, O. K. (2015). The Impact Of Classroom Management On Students' Academic Performance In Selected Junior Secondary Schools In Municipal Area Council. Abuja. International Journal of Education and Research, 142-142.

Koutrouba, K., Markarian, D.-A., and Sardianou, E. (2018). Classroom Management Style: Greek Teachers' Perceptions. International Journal of Instruction 11, 641-656.

Kromoprawiro (1867). Kawruh Sastro Pegon (Madiun: t.p.).

Lakshmi, H. V. (2017). Classroom Management in Integrated School Setup. Journal International Journal of Educational Sciences, 95-95. doi: 10.1080/09751122. 2010.11889994.

Madjid, N. (2012). Modernisasi Pesantren (Jakarta: Ciputat Press).

Maimun (2006). Strategi Pemanfaatan Sumber Belajar di Pondok Pesantren (Surabaya: IAIN Sunan Ampel Press).

Miles, M. B., Huberman, A. M., and Saldana, J. (2014). Qualitative Data Analysis, A Methods Sourcebook (New York: Sage Publications, Inc).
Moleong, L. J. (2010). Metodologi Penelitian Kualitatif (Bandung: Remaja Rosda Karya).

Muhaimin (2006). Strategi Belajar Mengajar (Surabaya: Citra Media).

Pudjiastuti, T. (1994). Pegon Scripts: Tangible Identity of Islamic-Javanese (Yogyakarta: UGM Yogyakarta).

Qamar, M. (2011). Pesantren dari Transformasi Metodologi Menuju Demokratisasi Institusi (Jakarta: Erlangga).

Sharma, S. (2017). Classroom Management for Effective Teaching Skills Among New Teachers And Academic Achievement Among Elementary Students. International Journal of Development Research 7, 14125-14128. doi: https://doi.org/ 10.37118.

Siradj, S. A. (2008). Pesantren Masa Depan (Cirebon: Pustaka Hidayah).

Sista, T. R., Baqi, S., and Budiman, A. (2019). The Implementation of Islamic Education in Student Moral Guidance on Traditional and Modern Pesantren Institution. PEOPLE: International Journal of Social Sciences 4, 1319-1338. doi: -https://dx.doi.org/10.20319/pijss.2019.43.13191338.

Smith, J. A. and Shinebourne, P. (2009). Interpretative Phenomenological Analysis: Theory, Method and Research (Los Angeles, London, New Delhi, Singapore, Washington: Sage).

Soebahar, A. H. (2013). Modernisasi Pesantren (Yogyakarta: LKiS).

Sugiyono (2012). Metode Penelitian Kuantitatif, Kualitatif dan R\&D (Bandung: Alfabeta).

Turmudi, E. (2009). Perselingkuhan Kiai dan Kekuasaan (Yogyakarta: LKiS).

Usman, M. U. (2003). Menjadi Guru Profesional (Bandung: Remaja Rosdakarya), $1-154$.

Conflict of Interest Statement: The author declare that the research was conducted in the absence of any commercial or financial relationships that could be construed as a potential conflict of interest.

Copyright $(2020$ Hartono. This is an open-access article distributed under the terms of the Creative Commons Attribution License (CC BY). The use, distribution or reproduction in other forums is permitted, provided the original author(s) and the copyright owner(s) are credited and that the original publication in this journal is cited, in accordance with accepted academic practice. No use, distribution or reproduction is permitted which does not comply with these terms. 